\title{
THE NEW PUBLIC MANAGEMENT AND LOCAL POLITICS IN SWEDEN
}

Pınar akarçay *

* Trakya Üniversitesi

E-mail: pinarakarcay@trakya.edu.tr

Copyright (C) 2015 pınar akarçay. This is an open access article distributed under the Eurasian Academy of Sciences License, which permits unrestricted use, distribution, and reproduction in any medium, provided the original work is properly cited.

\begin{abstract}
Since the late 1970s and 1980s local important legal reforms have been carried out in Sweden. In accordance with the basic argument of new public management reforms, has begun to transform the public administration. It is in the public sector in many countries such as Sweden which said the transformation of the competitive market in the public sector use of private sector management techniques and mechanisms of understanding to approximate. Particularly in local government has been involved in any changes to be made that the new local government act on the basis of "new public management" in accordance with the public in 1991. Therefore, this period of reform in the public sector responsibilities and resources in order to make effective and eliminate public criticism, the Central and the local market have being share.
\end{abstract}

Keywords: Key Words: New Public Management, Local Policy, New Public Administration, Central-Local Relations, Local Management

\section{İsveç’te Yeni Kamu İşletmeciliği ve Yerel Siyaset}

\section{ÖZET}

İsveç'te 1970'lerin sonu ve 1980'den itibaren önemli yerel yasal reformlar gerçekleştirilmiştir. Yapılan reformlar, yeni kamu işletmeciliğinin temel argümanlarına uygun olarak, kamu yönetimini dönüştürmeye başlamıştır. Söz konusu dönüşüm bir çok ülkenin kamu sektöründe olduğu gibi İsveç’te de kamu sektörünü rekabetçi piyasa mekanizmaları ile özel sektöre ait işletmecilik tekniklerinin kullanılması anlayışına yaklaştırmıştır. 1991'de hazırlanan yeni yerel yönetim yasasının temelinde "yeni kamu işletmeciliğgi" doğrultusunda kamuda özellikle yerel yönetimlerde yapılacak değişiklikler yer almıştır. Dolayısıyla bu dönem yapılan reformlarda, kamuya yönelik eleştirileri ortadan kaldırmak ve kamu sektörünü etkin hale getirebilmek için sorumluluklar ve kaynaklar, merkez-yerel ve piyasa arasında paylaştırırken, bir taraftan da yerel yönetimleri "yerel işletmeler” anlayışına kaydırmaya başlamıştır.

Anahtar Kelimeler: Anahtar Kelime: Yeni Kamu İşletmeciliği, Yerel Siyaset, Yeni Kamu Yönetimi, Merkez-Yerel İlişkisi, Yerel İşletmecilik 


\section{GíRiş}

İsveç'te 1970'lerin sonlarından itibaren önemli yerel yasal reformlar gerçekleştirilmiştir. Yapılan reformlar, yeni kapitalizmin ${ }^{1}$ temel argümanlarına uygun olarak, devleti ve toplumu değiştirmeye başlamıştır. Çok sayıda ülkenin kamu sektöründe olduğu gibi İsveç’te de kamu sektörü rekabetçi piyasa mekanizmaları ile özel sektöre ait işletmecilik tekniklerinin kullanılmasıyla yani kapitalizme uygun olarak büyük bir dönüşüm geçirmektedir. Bu dönüşüm, devlet- piyasa, devlet- bürokrasi, devlet-vatandaş ve bürokrasi-vatandaş ilişkilerini yeni kapitalizme uygun olarak yeniden tanımlamaktadır. Devletin ekonomik boyutunu, sosyoekonomik hayattaki rolünü ve kamu sektörüne egemen olan yönetsel değer ve uygulamaları hedef alan yeni bir siyasal hareket 1970'lerin sonlarından itibaren dünya siyasetinde hegemonyasını kurmuştur (Gjelstrup,2007:138). 1970'lerde ki ağır kapitalist krizin de etkisiyle devlet yönetimine piyasa kökenli kural ve mekanizmalarca yön verilmesini ön gören bu hareket 1990'ların başlarında merkezi planlı ekonomilerin çökmesiyle birlikte daha da güç kazanmış ve pek çok hükümet politikalarına yön vermiştir.

Bu yeni kamu yönetimi anlayışının kuramsal ayağı olan Yeni Kamu İşletmeciliği anlayışının yeni kamu yönetimine yansıması, piyasa ve benzeri mekanizmalar kullanmak suretiyle kamu kesiminde rekabeti özendirmek ve kamusal işlevlere işletmevari bir nitelik kazandırmak, kamu kaynaklarının kullanılmasında "maliyet" bilinci geliştirilerek kaynak tahsisi, ödüllendirme ve performans arasındaki ilişkiyi geliştirmek; geleneksel kamu bürokratlarını "kamu işletmecileri" haline dönüştürmek ve meşrulaştırmak yönünde olmuştur. Müşteri memnuniyetinin sağlanabilmesi ve talepler, tercihlerin belirlenmesi için "müşterilerin sürece katılımı" ve hizmet sunucuların "yerelleşmesi” anlayışına dayanan yeni kamu işletmeciliği, İsveç’te yapılan yerel reformlar üzerinde doğrudan etkili olduğu görülmektedir. Bu bağlamda İsveç’te yapılan önemli reformlardan bir diğeri, yerel otoritelerin piyasayla ilişkilerinin güçlendirilmesi yani bir ölçekte üretimde "piyasa gibi hareket etmek" için yasal düzenlemelerin geliştirmesi yönünde olmuştur.

1991'de hazırlanan yeni yerel yönetim yasasının temelinde 1985 yılında yapılmaya başlanan ve art arda yapılan kamu reformları yer almaktadır. Tüm dünyada olduğu gibi İsveç'te de bu dönemde refah devleti politikaları eleştirilmeye ve "yeni kamu işletmeciliği" doğrultusunda dönüşmeye başlamıştır. Dolayısıyla bu dönem yapılan reformlarda kamuya yönelik eleştirileri ortadan kaldırmak ve kamu sektörünü etkin hale getirebilmek için sorumluluklar ve kaynaklar, merkez-yerel ve piyasa arasında paylaştırılmıştır. Bu bağlamda merkezi yönetimin yetki ve görevleri gözden geçirilmiştir. Kamu hizmetlerinin yerine getirilmesinde kamu çalışanlarının ve özel sektör çalışanlarının ortak hareket etmesi düzenlenmiştir. Bu bağlamda yeni kapitalizmin özenle üzerinde durduğu konular dünyanın birçok ülkesinde olduğu gibi İsveç’te de tartışılmış ulusal ve yerel yasalarına yansıtılmıştır.

Bu makalede, 1991'de hazırlanan yeni yerel yönetim yasasında yer aldığı şekliyle yerel yönetimler ve yerel siyasetin işleyiş ve görevleri ile ilgili temel bilgiler arka planda çalışmada yer alırken, yeni kamu işletmeciliği anlayışı ve İsveç'in yerel yönetim ve siyasetine nasıl yansıdığı ve bu konuda yapılan tartışmalar üzerinde durulmaktadır. Makale kamu işletmeciliğinin İsveç'in yerel yönetimine etkisi üzerine odaklanmaktadır.

\section{ISVEÇ'TE YEREL SIYYASET}

İsveç'te bölgesel ve yerel yönetimler, Avrupa sözleşme belgelerine uygun olarak yerelde özerk yapıya sahiptir. İsveç'te bugün 21 bölge, 20 il konseyi, 290 belediye bulunmaktadır. İl konseyleri ve belediyeler formel olarak birbirinden bağımsızdır (Swedish Local Government

\footnotetext{
${ }^{1}$ Yeni kapitalizm kavramı, kavramsal netleştirme için neo-liberalizm kavramı yerine kullanılmaktadır.
} 
Act,1999). Bu birimler arasında hiyerarşik bir yapılanma yoktur. Özerktirler ve görevleri birbirinden farklıdır.

İsveç yerel yönetim yasas1 -Local Government Act- (Kommunallagen) 1991'de yürürlüğe girmiştir. 1998, 2001 ve son olarak 2003 yıllarında yasada Avrupa Birliğine uyum kapsamında kimi değişiklikler yapılmıştır. Yapılan değişiklikler sonucu Yerel Yönetimler Yasası'nın başlangıç kısmında, yerel yönetimlerin özerk olduğu ve özerk yerel yönetimlerin anayasanın tamamlayıcı demokratik parçası olduğu vurgulanmaktadır. Ayrıca yerel özerklik konusunda Avrupa Birliği kriterlerini kabul ettiği belirtilmiştir. Bu bağlamda yerel özerklik noktasında yerel yönetimlerin yetki ve kaynakları genişletilmiştir (Montin ve diğerleri, 1999:157-185).

Bu kanun 10 bölüme ayrılır (Swedish Local Government Act,1999): 1. bölüm belediyeler ve il meclislerini tanımlar ve görev alanlarını belirler. 2. bölüm belediyeler ve il meclislerinin yetkileri, 3. bölüm teşkilatlanmaları, 4. bölüm seçilmiş temsilciler, 5. bölüm belediye meclisleriyle -parlamentonun yerel karş1lığ1- ve 6. bölüm belediye yürütme komitesi hükümetin yerel karşıllı̆ı- ve diğer komiteleriyle ilgilidir. 7. bölüm ilgili tarafların oluşturduğu işbirliği kurumları ve çalışanların temsilcileriyle (ortak organlar) ve hizmeti veya kurumu kullanan kişiler ile çalışanların temsilcilerinden oluşan yerinden yönetim organlarını düzenler. 8. bölüm maliye idaresiyle ve 9 . bölüm denetimle ilgilidir. Tamamlayan 10. bölüm yerel yönetimlerin kararlarının yasallığını ele alır.

Bu kanunun 1. bölümünün 1. maddesi şöyledir: “İsveç’te kamu gücü, kaynağını tamamen halktan alır. Kamu yönetimi, özgür kamuoyu ve genel seçim hakkı ile oluşur. Kamu yönetimi, temsili ve parlamenter devlet sistemi ile yerinden yönetim yoluyla gerçekleştirilir. Kamu gücü kanunlar çerçevesinde kullanılır." (Swedish Local Government Act,1999)

1. bölümün 7. maddesi ise şöyledir: "İsveç’te yerinden yönetiminin temel birimleri belediyeler ve il (County) konsey/meclisleridir. Belediyeler ve il meclislerinde karar alma hakkı, seçilmiş meclisler tarafından kullanılır. Belediyeler ve il meclisleri, görevlerini yerine getirmek için vergi koyabilirler" (Swedish Local Government Act,1999).

Devlet üç düzeyde temsil edilir. Ulusal düzeyde Parlamento (Riksdag); bölgesel ve yerel düzeyde İl Meclisi/Konseyi (County Council - Landsting); yerel düzeyde belediye meclisleri (municipalities - Komuner) yer alır. Kısaca yerel yönetimlerin birimleri görevleri ve çalışma usulleri aşağıdaki başlıkta ele alınmaktadır.

\section{YEREL YÖNETIMLERİN ORGANLARI VE ÇALIȘMA USULLERİ}

Bu başlık altında aktarılan bilgiler, doğrudan İsveç yerel yönetim yasasından derlenmiştir.

Karar Organlar1;

Belediye Meclisi (municipal assembly)

İl Konseyi/Meclisi (County council assembly)

Meclisler, yalnız genel/yerel seçimlerde seçilen temsilcilerden oluşur. Kanununun Bölüm 5, Kısım 1'de meclislerde olması gereken meclis üye sayısının tespit şekli tarif edilir. En az üye sayısı, belediye veya il meclisinde oy hakkına sahip olanların sayısına göre belirlenir. Seçimlerde hem meclis üyeleri hem komite üyeleri hem de denetçiler seçilir. Meclis kaç üyesi olacağına kendisi karar verir. İsveç yerel yönetim yasasına göre bu sayı, en az 31 en çok 101 olarak belirlenmiştir. Bu sayı bölgede oy verenlerin sayılarına bağlı olarak değişmektedir. Belediye ve İl başkanını meclis seçer. Başkanların ne kadar süre hizmet vereceğine meclisler karar verirler. 
Meclis üye sayıları tek sayı olmalı ve şunlardan az olmamalıdır;

31 Üye 12.000 veya daha az seçmenin yaşadığı belediyelerde ve 140.000 veya daha az seçmenin yaşadığ 1 il meclislerinde

41 Üye $\quad 12.000$ 'le 24.000 arasında seçmenin yaşadı $\breve{g} 1$ belediyelerde

51 Üye $\quad 24.000$ ile 36.000 arasında seçmenin yaşadı $\breve{g ̆}_{1}$ belediyelerde ve 140.000 'le 200.000 arasında seçmenin yaşadığı il meclislerinde

61 Üye $\quad 360.000$ 'den fazla seçmenin yaşadığ belediyelerde

71 Üye 200.000'den fazla seçmenin yaşadığı il meclislerinde

Ayrıca Stockholm Belediyesi ile 300.000'den fazla seçmenin yaşadığı il meclislerinde üye sayıs1 101'den az olamaz.

Meclislerin üyeleri, her dört yılda bir parlamento seçimleriyle beraber aynı günde yapılan mahalli genel seçimlerde seçilirler. Görev dönemi, seçim yılının 1 Kasımında başlar. Seçme yeterliliği olanlar, seçimlere katılan farklı partiler için oy kullanırlar. Meclisteki sandalyeler, partiler arasında aldıkları oylarla orantılı olarak dağıtılır.

Belediye meclis üyesi aynı zamanda il meclisi üyesi sayılmaktadır. Her belediye gelir vergisini kendisi belirlemektedir. Belediye ve il meclisi kendi aralarında ya da uluslararası ölçekte işbirliği kurabilirler. Bu konuda yasada çok net herhangi bir kural öngörülmemiş yerel yönetimlere bırakılmıştır (Swedish Local Government Act,1999). Belediye meclis üyeleri ve il meclis üyeleri aksi sebepler olmadıkça eşit haklara sahiplerdir.

Belediyeler ve il Meclisleri ticari işlere girişebilirler, şirket kurabilirler, vakıf ve dernek kurabilirler, ticari işbirliği ilişkisi geliştirebilirler². Ayrıca kamusal yaşamı kolaylaştıracak başka hizmetleri de yapabilirler. Yerel yönetimler, kendilerine ait, merkezden ayrı özerk bütçe ve personelleri bulunmaktadır. Partilerden ve merkezden ödenek almakla birlikte kendi bölgelerindeki gelir vergisi yerel yönetimlere aittir. Partilerden alacakları ödeneklerin kapsamına yerel yönetim meclisleri karar verir. İstenen desteğin haksız olmayacağ belirtilmiştir (Swedish Local Government Act,1999).

Meclis toplantıların ne zaman ve nerede yapılacağına karar verir. Meclis toplantıları belediye başkanı/ il başkanı tarafından en az 1 hafta önce kamuya duyurulur. Bu duyuru toplantının yeri zamanı ve nelerin görüşüleceğini içerir. Duyurular, yerel yönetimin duyuru panosunda ayrıca günlük yerel gazetelerde duyurulur. Ayrıca meclis üyelerine gönderilir. Karar için yarıdan fazla üyenin oluru gereklidir (Swedish Local Government Act,1999). Meclis kararları tutanakla kaydedilir ve halka duyurulur. Alınan kararla birlikte, tartışmalar, teklifler, karar çoğunluğu, katılan üyeler duyuru metnine dahil edilir.

Yürütme Organları;

Belediye yürütme komitesi;

İl Konseyi/Meclisi yürütme komitesi;

\footnotetext{
${ }^{2} \mathrm{Bu}$ düzenleme yeni yerel yönetim yasasıyla geliştirilmiştir.
} 
Yürütme komiteleri meclisler tarafından atanır. İl meclisi, il yürütme komitesini, belediye meclisi, belediye yürütme komitesini seçer ve atar. Meclisler, oy hakkı olan ve genel seçimde aday olanlar arasından seçerler (Swedish Local Government Act,1999).

Belediyenin (siyasi) lideri, belediye yürütme komitesi başkanıdır ve bunun il meclisindeki karşılığı il meclisi başkanıdır. Diğer Avrupa ülkelerinin aksine İsveç'te tek adam anlayışı yoktur. Bu nedenle bu başkanların karar alma yetkileri oldukça sınırlıdır. Kararlar meclisler tarafından alınırlar. Ayrıca yürütme komitesi başkanları meclisler tarafından atanır. Yürütme komitesinin üye sayısını ve görev sürelerini yerel meclisler belirler (Swedish Local Government Act,1999). Bu sayı yasaya göre beşten az olamaz. Yürütme komitelerinin altında görev alanlarına göre farklı sayıda ve isimde komiteler bulunur.

Her ilin ve belediyenin karar organı olan meclislerinin yanı sıra yürütme komiteleri ve buna bağlı diğer (eğitim, planlama, sağlık vb.) ilgili alanlarda komiteler bulunmaktadır. İl meclisi ve belediye meclisi yürütme komitesi üyelerini kendi içinden atar (Swedish Local Government Act,1999). Bunun için yine kendi üyelerinden oluşmuş komite hazırlama meclisi de oluşturabilir. Ayrıca komitelere denetçi atar. Komiteler meclise görevlerinde yardım ederler. Komiteler faaliyetleriyle ilgili olarak yerel meclislere rapor verirler. Meclis bu raporlar aracılığıyla komitelerin görevlerini aktif olarak yerine getirip getirmediğini denetler.

Yürütme komitesinin başlıca görevleri şöyledir; Diğer komiteleri gözetlemek ve idare etmek, finansal konularda gerektiğinde meclise önerilerde bulunmak, göreviyle ilgili diğer komiteler ve yerel yönetim çalışanlarından açıklama ve bilgi isteyebilir, meclisin kendisine verdiği görevleri yerine getirir (Swedish Local Government Act,1999). Ayrica komitelerin de başkanları vardır. Yine bu başkanlar yerel meclisler tarafından belirlenir.

\section{Şekil I; Yerel Komiteler}

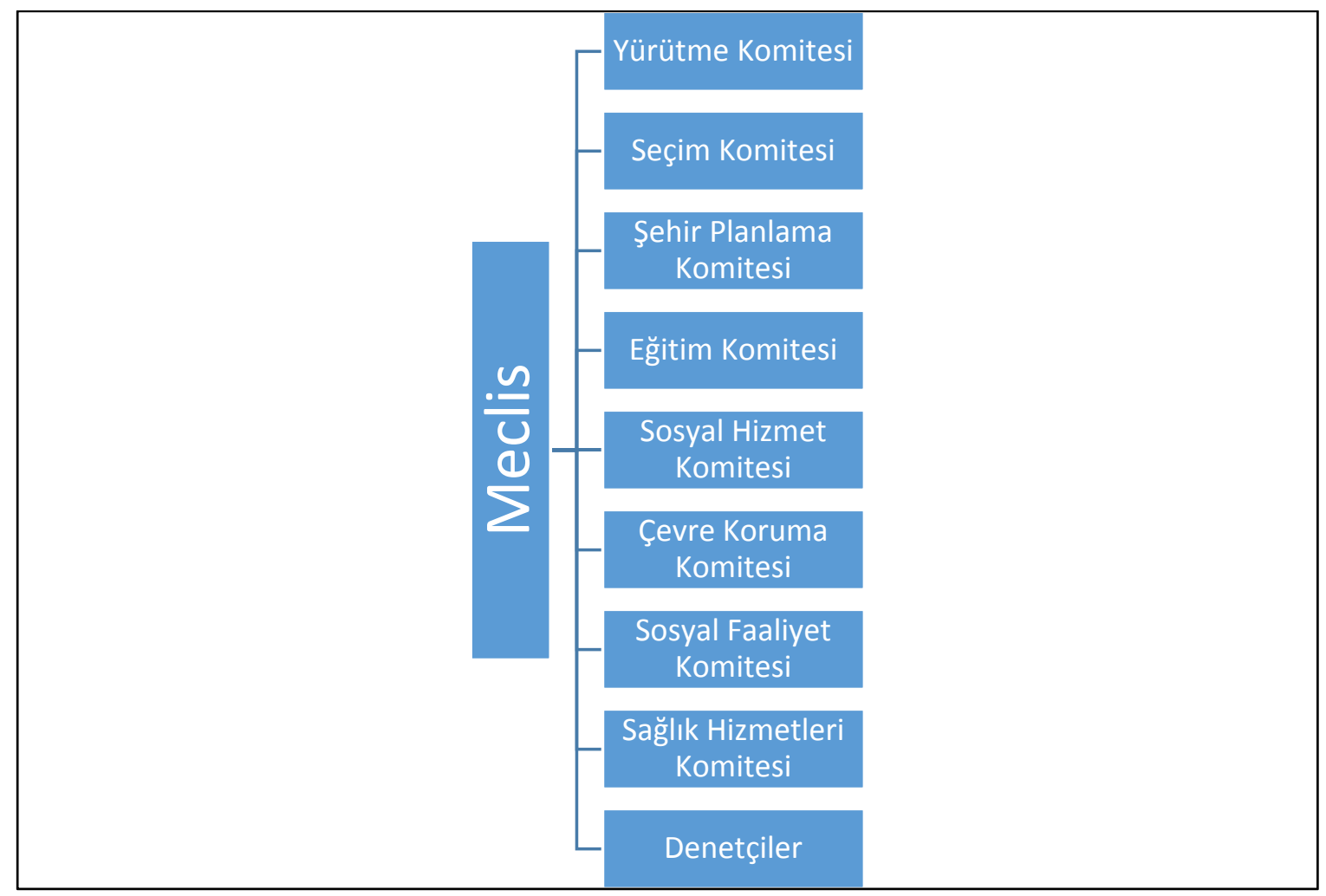




\section{Meclislerin Görevleri;}

Meclisler, belediye veya il meclisi idaresinin öncelikli veya çok önemli konularıyla ilgili kararlar verir. Bunlara örnek vermek gerekirse özellikle aşağıdaki konular belirtilebilir:

Faaliyetler için hedef ve usullerin tespit edilmesi,

Bütçe, vergilendirme ve diğer önemli mali konular,

Komitelerin teşkilatlanması ve çalışma usulleri,

Komitelerin seçimi ve komitelere görevlerin dağıtımı,

Denetçilerin ve yedeklerinin seçimi,

Seçilmiş temsilcilerin mali kazançlarının tespiti,

Y1llk rapor ve bunun ibras1.

Komitelerin Görevleri;

Komiteler, yönetimle ilgili konularda ve kanun veya hukuki düzenlemelerle kendilerine görev olarak verilen konularda karar verir.

Komiteler, ayrıca meclis tarafindan kendilerine verilen konularda da karar verirler.

Komiteler konuları meclis için hazırlar ve meclis kararlarının uygulanmasından sorumludur.

Komiteler, meclis tarafından kendilerine emanet edilen işlerin uygulanması için aldıkları tedbirleri meclise rapor ederler.

Belediyelerin ve il meclislerinin bir karar alma organına (meclis) ve bir yürütme komitesine sahip olması zorunludur. Meclis, yönetim ve görevlerin yürütülmesi için gerekli komiteleri oluşturmakta serbesttir (Swedish Local Government Act,1999). Ayrıca kanun, denetçilerin atanması ve seçilmesini de hüküm altına almıştır.

Şekil II; Yerel Yönetimlerin Politik Sitemdeki Yeri

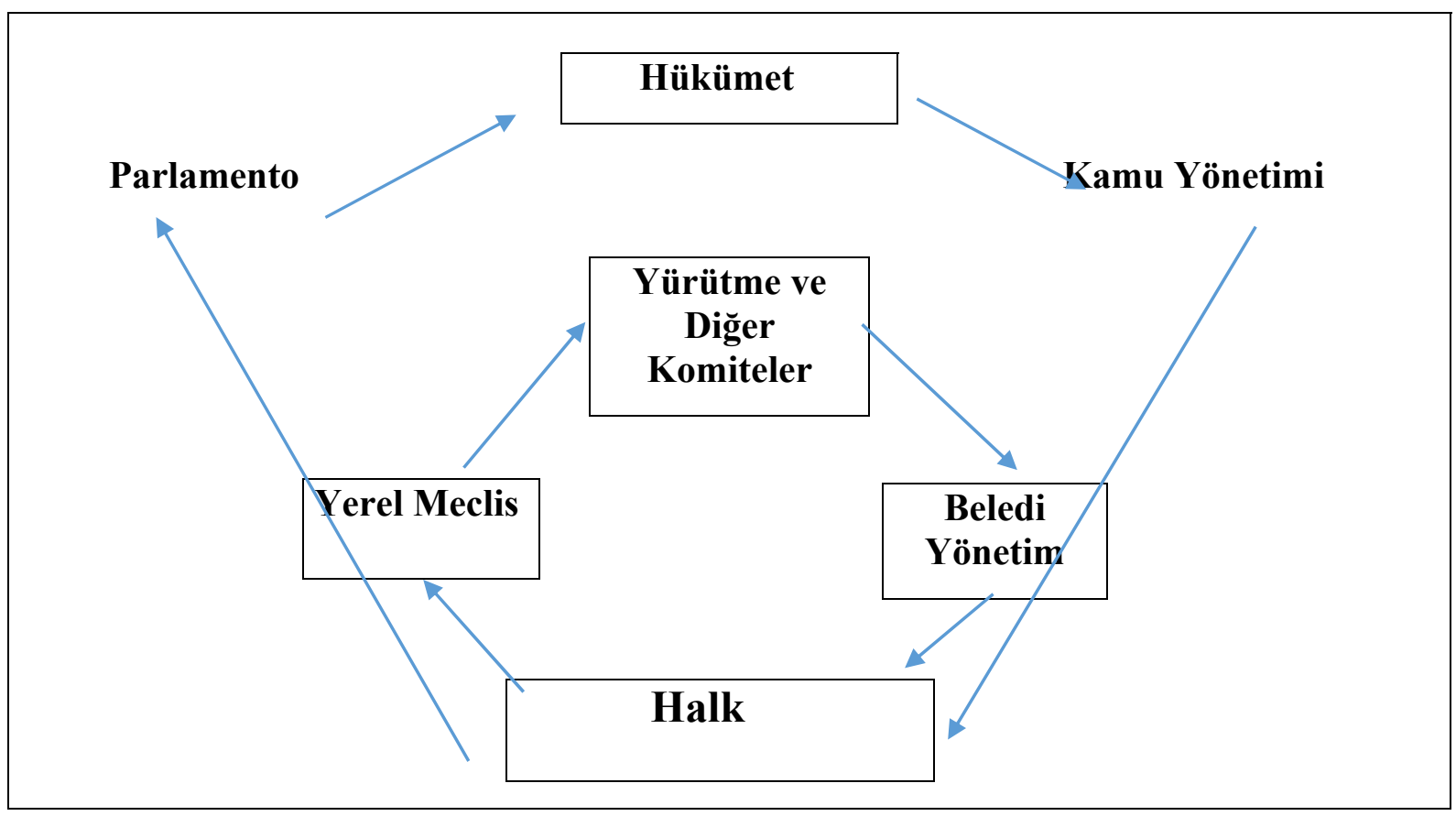




\section{KAMU İŞLETMECILİĞİ OKULU}

Anglo-Amerikan dünyası başta olmak üzere çok sayıda ülkenin kamu sektörü rekabetçi piyasa mekanizmaları ile özel sektöre ait işletmecilik tekniklerinin kullanılmasıyla yani kapitalizme uygun olarak büyük bir dönüşüm geçirmektedir. Bu dönüşüm, devlet- piyasa, devlet- bürokrasi, devlet-vatandaş ve bürokrasi-vatandaş ilişkilerinde önemli anlam karmaşasını yeni kapitalizme uygun olarak yeniden tanımlamaktadır.

Devletin ekonomik boyutunu, sosyo-ekonomik hayattaki rolünü ve kamu sektörüne egemen olan yönetsel değer ve uygulamaları hedef alan yeni bir siyasal hareket 1970'lerin sonlarından itibaren dünya siyasetinde hegemonyasını kurmuştur. 1970'lerde ki ağır kapitalist krizin de etkisiyle devlet yönetimine piyasa kökenli kural ve mekanizmalarca yön verilmesini ön gören bu hareket 1990'ların başlarında merkezi planlı ekonomilerin çökmesiyle birlikte daha da güç kazanmış ve ciddi bir muhalefetle karşılaşmadan pek çok hükümetin resmi politikalarına yön vermiştir (Gjelstrup ve diğerleri,2007:53-54).

Yaşanan ekonomik krizin etkisiyle bazı siyasal ve ekonomik teoriler (kamu tercihi, kamu işletmeciliği, işlem maliyeti, mülkiyet hakları teorileri) kamu sektörüne ve özellikle kamu bürokrasisine yönelik bu siyasal ve ideolojik saldırılarda teorik bir destek sağlamıştır. Geleneksel kamu yönetiminin kamu yararı gibi temel değer ve nosyonlarının yerini piyasa kökenli alternatif değer ve nosyonların almasıyla geleneksel kamu hizmeti sunma anlayışı da yerini yavaş yavaş ekonomik hizmet sunma anlayışına bırakmıştır (Tullock,1965:62).

Yeni Kamu İşletmeciliği Okulu, tüm bu değişmeleri bize şöyle sunmaktadır (Pierre ve diğerleri,2000:77); piyasa ve benzeri mekanizmalar (market-type mechanisms) kullanmak suretiyle kamu kesiminde rekabeti özendirmek ve kamusal işlevlere işletmevari bir nitelik kazandırmak; "iç piyasalar" yaratmak suretiyle kamu hizmeti planlaması ile üretimi ve sunumu işlevlerini birbirinden ayırmak; devletin küçültülmesi ve piyasanın egemen kılınması politikası çerçevesinde hizmet sunma işlevini hem iç (kamu kuruluşları ve alt birimleri) hem de diş (özel şirketler ve STK'lar) rekabete açmak; kamu sektöründeki mali ve hiyerarşik denetime dayanan geleneksel ilişki yerine hizmeti sağlayan iç ve dış müteahhit firma ile hizmeti satın alan kamu kuruluşu arasında sözleşmeye dayalı bir ilişki kurmak; kamu hizmetlerinin yürütülmesinde "rasyonel" ve "stratejik" bir yaklaşım benimsemek ve kurala yönelik bir yönetim tarzından amaca yönelik yönetim tarzına geçmek; önceden belirlenmiş performans hedeflerine ulaşmak ve çeşitli düzeylerdeki yöneticileri bu sonuçlardan sorumlu tutabilmek için kamu örgütlerindeki hiyerarşik düzeyleri azaltıp daha yalın hale getirmek ve mali ve yönetsel bazı yetkileri onlara devretmek; kamu kaynaklarının kullanılmasında "maliyet" bilinci geliştirilerek kaynak tahsisi ve ödüllendirme ve performans arasındaki ilişkiyi geliştirmek; geleneksel kamu bürokratlarını "kamu işletmecileri” haline dönüştürmek ve meşrulaştırmak (Pierre ve diğerleri,2000:79).

Daha önemli bir diğer nokta, kamu kuruluşlarının yapılarını daha "esnek" ve işleyişi -görecedaha "şeffaf" hale getirmek ve "hizmeti satın alan kullanıcı yada müşterilere" farklı hizmet sağlayıcılar arasında tercih yapabilecek mekanizmaları geliştirmek. Müşteri memnuniyetinin sağlanabilmesi ve talepler, tercihlerin belirlenmesi için "müşterilerin sürece katılımı" ve hizmet sunucuların “yerelleşmesi”" son derece önemlidir (Bağlija,2008:39-42).

Yeni Kamu İşletmeciliği Okulu'nun temel ideolojisi yeni kapitalizme dayanmaktadır (Bağlıja,2008:45). Geniş anlamıyla ele alındığında kamu sektörünün işletmevari bir niteliğe kavuşturulmasının kamu sektöründeki kültür ile güç, kontrol ve sorumluluk ilişkilerini temelinden değiştiren “ideolojik bir süreç”tir. Bu süreçte, refah devleti, kamusal hizmet sunumu ve bürokratik güç ilişkileri üzerine kurulmuş olan konsensüs ortadan kaldırılmaya ve yeni 
kapitalist ideoloji çerçevesinde piyasanın sürekliliği ve güvenliği için devletin yeniden yapılandırılması projesini uygulamaya koyma çalışmaları yürütülmüştür (Bağlija,2008:45).

Her ne kadar Yeni Kamu İşletmeciliği'nin kökleri Taylor'un Bilimsel Yönetim Akımı gibi geleneksel yönetim teorilerine ve İngiliz kamu yönetimi için düzenlenen Fulton Raporu (1968) gibi bazı resmi reform raporlarına götürülebilse de Yeni Kamu İşletmeciliği ve "yeni kapitalizm" ideoloji arasındaki ilişki barizdir (Pierre ve diğerleri,2000:79). Uluslararası ekonomik ve mali krizin dışa açılma ve serbest piyasa mekanizmasının ilkelerini bütün ekonomik ilişkilerde egemen kılmaya çalışan yeni kapitalist ideoloji Yeni Kamu İşletmeciliği ile örtüşmektedir. Siyasal-bürokratik "karar verme süreçlerine" piyasa mekanizmalarının önderliğinde "kullanıcıların" katılımını desteklenmesi Yeni Kamu İşletmeciliğinin yeni kapitalist söylemlerle paralel olarak çizdiği rekabet ve firma devlet/yönetim anlayışının bir uzantısıdır. Dolayısıyla firma gibi hareket eden kamunun Kamu İşletmeciliği anlayışının, kamu yönetimine uyarlanmış hali olarak kamunun firmalaşmasını, işletme/firma mantı̆̆ının bir uzantısı olarak karı ve verimliliği arttırmak, maliyetleri düşürmek için gerekliliğini üstü örtülü olarak vurgulanmıştır.

\section{YENI KAMU İŞLETMECİL̇Ğİ OKULUNUN ETKİSI VE İSVEÇ’TE 1980 SONRASI YEREL SIYYASET}

1970'lerde ki ağır kapitalist krizin de etkisiyle devlet yönetimine piyasa kökenli kural ve mekanizmalarca yön verilmesini ön gören kamu işletmeciliği anlayışı 1990'ların başlarında merkezi planlı ekonomilerin çökmesiyle birlikte daha da güç kazanmış ve ciddi bir muhalefetle karşılaşmadan, birçok Avrupa ülkesinde olduğu gibi İsveç’te de pek çok hükümet politikalarına yön vermiştir (Murphy,2009:120).

İsveç'te özellikle geleneksel kamu yönetiminin kamu yararı gibi temel değer ve nosyonları, kamu işletmeciliği anlayışıyla, yerini piyasa kökenli alternatif değer ve nosyonların almasıyla geleneksel kamu hizmeti sunma anlayışı da yerini piyasalaşan kamu hizmeti sunma anlayışına bırakmıştır (Rose ve diğerleri,2005:89).

Dünyada yaşanan bu kamu işletmeciliği dönüşümünün İsveç'e yansıması 1970'lerin sonlarından itibaren önemli yerel yasal reformlar kendini hissettirmiştir. Kamunun özellikle yerel yönetimlerin işletme mantığına yaklaştırılması, kamu hizmetlerinde müşteri memnuniyetinin -vatandaş yerine kullanılan- sağlanabilmesi ve talepler, tercihlerin belirlenmesi için "müşterilerin sürece katılımı" ve hizmet sunucuların "yerelleşmesi" son derece önemli hale getirilmiştir (Strömberg,1984:63).

Yapılan reformların en önemlilerinden birisi, yeni kamu işletmeciliğinin temel argümanlarına uygun olarak, vatandaşların yerel politik sürece geniş ölçekli etki yaratabilmeleri için "birlikte politika yapma" süreçleri geliştirmek olmuştur (Duros ve diğerleri,2009:27-30). İkinci olarak, bunu sağlamak için seçilmiş temsilciler, profesyonel gruplar ve yarı profesyonel gruplar arasında yasal bir konsensüs yaratılmaya çalışılmıştır. Ayrıca bunu "Güçlendirilmiş Profesyonalizm" ya da "Etkisi Güçlendirilmiş Halk" Sloganlarıyla geliştirmek belirlenen amaçlardan birisi olmuştur (Lewin,1994:63-65). Üçüncü olarak, belediye hizmetlerinden yararlananların da uygulamaya katılabilmesi için reformlar geliştirmiştir. Dördüncüsü, yerel otoritelerin piyasayla ilişkilerinin güçlendirmesi yani bir ölçekte üretimde "piyasa gibi hareket etmek" için yasal düzenlemeler geliştirilmiştir (Duros ve diğerleri,2009:31). Böylece yeni yerel modelde, politik kararların oluşmasında yurttaş “politik girdi”yi, kullanıcılar, müşteriler ve tüketiciler "politik çıktı"yı oluşturmaktadır. 
1991 'de hazırlanan yeni yerel yönetim yasasının temelinde 1985 yılında yapılmaya başlanan ve art arda yapılan kamu reformları yer almaktadır. Tüm dünyada olduğu gibi İsveç'te de bu dönemde refah devleti politikaları eleştirilmeye ve "yeni kamu işletmeciliği" doğrultusunda dönüşmeye başlamıştır (Gustafsson,1999:46). Dolayısıyla bu dönem yapılan reformlarda kamuya yönelik eleştirileri ortadan kaldırmak ve kamu sektörünü -görece- etkin hale getirebilmek için sorumluluklar ve kaynaklar paylaştırılmıştır. Bu bağlamda merkezi yönetimin yetki ve görevleri gözden geçirilmiştir.

Kamu hizmetlerinin yerine getirilmesinde kamu çalışanlarının ve özel sektör çalışanlarının ortak hareket etmesi düzenlenmiştir. Bu bağlamda yeni kamu işletmeciliğinin tüm dünyada özenle üzerinde durduğu konular İsveç'te de tartışılmış ulusal ve yerel yasalarına yansıtılmıştır. Dolayısıyla halkın kamu hizmetlerine ve kamu yönetimine katılımı da vurgulanan önemli konulardan birisi olmuştur.

1980'li yılların ortalarından sonra "katılımcılık", "anayasal ve yasal" güvenceler altına alınmaya başlamıştır. 1991'de hazırlanan yerel yönetim yasasıyla yerel ve merkezi yönetimin yetki ve sorumlulukları ayrılmıştır. Böylece bu yasayla mümkün düzeyde yetkiler merkezden yerele kaydırılmıştır. Kaydırılan bu yetkilerde yerel ve özel sektör arasında paylaştırılmıştır. Yapılan reform sonrası merkez ve yerel arasındaki görev ve yetki ayrımı şu şekilde ayrıştırılmıştır (Gustafsson,1999:49);

Çöp toplama hizmeti; Bu hizmet yerel yönetimlerin sorumluluğundadır. Yerel bunu yerine getirirken özel sektörle birlikte hareket edebilir.

Sağlık hizmetleri; Sağlıkla ilgili genel politika merkez tarafından belirlenmektedir. Daha küçük ve yerel çaplı, hastane hizmetleri koruyucu sağlık hizmetleri gibi hizmetler yerel yönetimlerin sorumluluğundadır. Özel sektör bu hizmetlerin yapılmasına dahil edilebilir. Hatta sağlık hizmetlerinde özel sektör genişlemekte ve büyümektedir.

Eğitim hizmetleri; Anaokulu, ilkokul, lise yerel yönetimler ve özel sektör birlikte hareket edebilir. Yükseköğrenim ise merkezi yönetimin sorumluluğundadır. Merkez özel sektörle birlikte bu hizmeti gerçekleştirebilir.

Sosyal hizmetler; Sosyal hizmet politikaları merkez tarafından belirlenir. Uygulamasını yerel yönetimler gerçekleştirir. Ancak çocuk ve yaşlı bakımı hizmetleri yerel yönetimlere bırakılmıştır. Yerel bunu özel sektörle birlikte yapabilir.

Su kaynakları; Yerel yönetimlerin sorumluluğundadır. Özel sektörle ortak çalışabilirler.

Yollar, caddeler, parklar; Yerel yönetimlerin sınırları içerisindeki yol, cadde ve park hizmetleri yerel yönetimlere aittir. Yerel yönetimlerin sınırları dışında kalanların sorumluluğu merkeze aittir.

Toplu taşıman hizmetleri; Şehir içi taşımacılık hizmetini yerel yönetimler sağlarken, şehirlerarası taşımacılık hizmetini merkezi yönetim üstlenmektedir.

Konut hizmetleri; Bu hizmet çoğunlukla özel sektör tarafından yerine getirilir.

Planlama hizmeti; Bu hizmet yerel yönetimler tarafından yerine getirilir.

Ayrıca görevlerini en iyi şekilde yerine getirebilmeleri için yeni bir finansal plan belirlenmiş ve yerelin gelirleri arttırılmıştır. Bu bağlamda yerel yönetimlerin vergi koyabileceği, şirket kurabileceği, ekonomik ve sosyal konularda iç ve diş ilişkiler geliştirebileceği düzenlenmiştir 
(Karlsson,2012:810). Ayrıca yerel yönetimlere sivil toplumu canlandırma, yerel yönetim ve sivil toplum ilişkisini geliştirme görevleri de verilmiştir.

1990'lardan itibaren "katılımcı demokrasinin” oldukça önemli olduğunu vurgulayan düzenlemeler geliştirilmiştir. Katılımcı demokrasi vurgulanmıştır. Sorumlulukların merkezden yerele aktarılması, yerelinde bu sorumlulukları yerine getirirken "özel sektör ve sivil toplum kuruluşlarıyla" ortaklaşmasının altı çizilmiştir. Böylece yetkiler merkezden yerele aktarılmış, yerelde de STK ve özel sektörle paylaşılmış olacaktır (Laffin,1986:56).

Fakat kimi İsveçli yazarlara göre, bu gerçek anlamda bir demokratik reform olamamıştır. (Montin,1993:68) Dolayısıyla gerçek anlamda etkili bir yönetim getirmek yerine, yeniden tanımlamıştır. Belediyeler için reformların piyasa gibi işleyen yerel yönetimler kısmı önem kazanmış, demokratik tartışmalar ikinci plana atılarak önemini kaybetmeye başlamıştır. ${ }^{3}$

1980'li yıllarda başlayan ve 90'lar ve 2000'lerde devam eden kamu yönetimi reformlarıyla, yönetimde etkinlik, verimlilik, performans üzerine kurulu yasal düzenlemeler yapılmıştır (Montin,1993:59). Böylece yeni kamu işletmeciliği politikalarıyla uyumlu olarak, kamusal hizmetler, üretici ve tüketici arasındaki ilişkinin gelişmişlik düzeyine bağlanmıştır. Üretici ve tüketici ne kadar uyumlu ise üretim o kadar verimli olur anlayışı kamuda yerleştirilmeye çalışılmıştır. Dolayısıyla yerel yönetimlerle, "müşteriler" yada "kullanıcılar" (bireysel yada örgütlü) arasındaki diyalog ve uzlaşma yeni kamu yönetimi anlayışının en önemli konusu haline gelmiştir (Montin ve diğerleri,1999:63).

İsveç’te diğer birçok Avrupa ülkelerinde olduğu gibi 1980'li yılların ortalarından beri, belediyelerle ilgili yasal düzenlemeler "kullanıcıların katılımını, yönetimin verimliliğini ve etkisini” arttırmak yönünde olmuştur (Anthonsen,2012:121) . Kullanıcı kavramı, vatandaş (brukare) kavramının yerini almıştır. Bu kavram 1970'li yılların sonunda Belediye Demokratik Komitesi'nde kullanılmış ve temsili demokrasiyi tamamlayan bir kavram olarak ele alınmıştır.

1980'lerden sonra yasal düzenlemelerle desteklenerek, belediyelerde, özel sektör, kullanıc1 müşteri etkisi birinci plana alınmış ve belediyelerin müşterilerin ve özel sektörün karar alma süreçlerine ve kamusal hizmet sunumuna etkilerini arttıracak yasal düzenlemelere gidilmiştir (Anthonsen,2012:123). Fakat bu yıllarda İskandinav ülkelerinde yapılan araştırmalar göstermiştir ki özel sektörün ve müşterilerin etkisini ve katılımını arttırmada kimi zorluklar yaşanmıştır (Premforms,1991:103). En önemli problem kullanıcı ya da müşteri kavramının tanımlanamaması olmuştur. Tam olarak kimler kast edilmektedir? Ayrıca kullanıcıların katılımı ve temsili demokrasi arasındaki denge nasıl sağlanacaktır?

Böylece İsveç'te yapılan kamu yönetimi reformları sonrası ortaya çıkan kavram ve denge karmaşası yoğun tartışmaları beraberinde getirmiştir. Ortaya çıkan görüşlerden bazısı, belediyelerde kullanıcılarla -özel sektör ve müşteriler- doğrudan iletişim kuracak bir görevli ya da görevlilerden oluşan danışma birimleri kurulmalı bunlar kullanıcıların görüşlerini, talep ve isteklerini karar süreçlerine yansıtmalıdır (Premforms,1991:105). Uygulama şansı daha zor olan diğer bir görüşe göre ise, belediyelerde ayrı bir meclis ya da birim oluşturulmalı kullanıcılar doğrudan hak sahibi olmalı, sandalye ve oy hakları olmalıdır (Strömberg,1984:13).

Dönemin İsveç hükümeti kafaların karışık olduğu bu konuyu açıklığa kavuşturmak için her iki görüşü de reddederek yeni yerel yönetim yasasını hazırladı. 1991'de yürürlük kazanan yeni yasayla özel sektör temsilcisi/temsilcileri mutlaka süreçte yer alacak şekilde, müşterikullanıcıların etkisi ise bağlayıcı olmayacak, danışma niteliğinde olacağı şeklinde

\footnotetext{
${ }^{3}$ Detaylı Bilgi için Bkz. Stig Montin, Swedish Local Government in Transition, 1993, Örebro Studies
} 
düzenlenmiştir. (Montin,2000:119) Bu anlamda müşterilerle ve özel sektörle ilgilenme görevi yerel komitelere (yürütme birimleri) verilmiştir. Komiteler hizmet sunarken, özel sektör ve kullanıcılardan görüş ve tavsiyeleri alıp, onları konuyla ilgili bilgilendiren, karar alma süreçlerine dahil eden, diyaloğu ve uzlaşmayı sağlayan birimler olarak yeniden düzenlenmiştir (Montin,2000:121). Bunun için yeni yasada belediyelere istedikleri konuda ve sayıda komite oluşturma serbestliği tanınmıştır (Wise,1998:20). Ayrıca komitelerin sayısının arttırılması ve daha çok kullanıcıyı kapsayacak şekilde genişletilmesi istenmiştir. Bu düzenlemeyle İsveç’te ki birçok belediye komite sayısını arttırmıştır (Montin,2000:123). Böylece yerelde kamu işletmeciliği uygulamaları "komiteler" üzerinde hayata geçirilmeye çalışılmıştır

Böylece temel yerel yönetim aktiviteleri için vatandaşın etkisi temsili demokrasi aracılığıyla gerçekleşirken, özel sektörün ve kullanıcı veya müşterilerin etkileri hizmet aldıkları komiteler kanalıyla gerçekleştirilmektedir. Montin'e göre, bu düzenlemede önemle vurgulanması gereken şeyin özel sektörle yakınlaştırılan yerel yönetimlerin önem kazandığı, vatandaşın yerine kullanılan kullanıcıların etkisinin politik alanın dışına itildiğidir (Montin,2000:125). Böylece katılımcılık çığırtkanlığının nedeni kaynakların doğru ve yerinde kullanılmasının tespit edilmesidir. Talebi belirlemek ve ona göre dağıtım yapmaktır. Birçok kamu hizmetini artık piyasaya gördüren belediyeler için, sermayeye müthiş bir hizmettir! (Strömberg,1984:12).

Yeni kamu yönetimi anlayışının yerel yönetimlerde "demokrasi ve verimlilik" ilişkisi tartışması "ne kadar seçilmiş temsilci ve komite olmalı" tartışmasına dönüşmüştür. (Strömberg,1984:15) Belediye Demokrasi Komitesi (Municipal Democracy Commission) demokrasi için daha çok komite olması gerektiğini tartışırken, İsveç Yerel Otoriteler Birliği (SALAR) verimlilik için daha az komite olması gerektiğini tartışmıştır. (SALAR,2006). 1980'li yıllar boyunca demokrasi ve verimlilik tartışmasına yine yeni yerel yönetim yasası noktayı koymuş ve kararı belediyelere bırakmıştır. Buna göre komitenin türü ve sayısını belirlemek belediyelere bırakılmıştır. (SALAR,2006)

1980'li yıllara damgasını vuran demokrasi ve verimlilik tartışmaları yeni kamu işletmeciliği üzerine oturtulan kamu yönetimi anlayışının temelini oluşturan siyaset ve üretim arasındaki ilişkiden gelmektedir (Montin ve diğerleri,1995:167). Temel mesele üretim servislerinin üretimi doğrudan kontrol altında tutabilmek için ne türde ve ne ölçüde beledi birimlerin geliştirilmesidir. Böylece belediyeler, tıpkı piyasa gibi ve piyasa mantığıyla hizmet üreten firma gibi girdi ve çıktıları kontrol eden birimler haline getirilmiştir (Montin ve diğerleri,1995:169). Yani piyasanın kavramları ve aklı belediyelere aktarılmıştır. Böylece rekabet kuralları içinde piyasa gibi sözleşme yapmak ve hizmet sunmak, kar ve zarar hesapları yaparak gerekli gördüğü hizmetleri piyasalaştırmak gibi anlayışlar belediyelerin amaç ve görevleri arasında sayılmıştır (Montin ve diğerleri,1995:170).

Montin'in yeni yerel yönetim yasasında altını çizdiği iki konu var; yeni yasanın yerel yönetimlere getirdiği "hedef yönetimi", diğeri "sipariş performansı organizasyonu" (bestallar utförarorgonisation) bu iki anlayış bir yandan verimlilik, kalite, kar, zarar gibi kavramlarla kamunun piyasalaşmasına odaklanırken, diğer yandan hizmet üretim birimlerini politik süreçlerden bağımsızlaştırıyor (Montin ve diğerleri,1995:170). Önemli diğer bir konu da yerel yönetimlerin hizmetlerini özelleştiriyor olmasıdır (Larsson ve diğerleri,2008:86-87).

Yeni yasanın amacı, devlet ve toplum, özel sektör arasında arasında yeni tür düzenlemeler bulmaktır. Montin'e göre yapılan bu reformlar, daha önceki reformlardan tamamen farklıdır. Örneğin yeni modelde desteklenen "sipariş komiteleri" hem iç hem diş hizmet sağlayıcı birimler (hem kamu hem özel) arasında iletişim ve uzlaşma sağlamaktadır. Dolayısıyla, İsveç'in korporatist kültürü yeni kapitalist politikaların etkileriyle “özellikle yerel düzeyde özel sektörü 
yeni tür korporasyonun baskın tarafları haline getirmektedir”. Dolayısıyla yerel politikalar özel sektörün ihtiyaçlarına göre ayarlanmaya başlamıştır (Larsson ve diğerleri,2008:89) Bu anlamda İsveç'in geleneksel korporatizmi yerel düzeyden ziyade merkezi düzeyde daha güçlü hale gelmiştir (Larsson ve diğerleri,2008:90). Yasayla kullanıcıların -özel sektör ve müşterilerkarar alma süreçlerinde etkisinin ve katılımın arttırılması desteklenmektedir. Fakat katılım süreçleri politik alanın dışına itildiği ve müşteri talebini kontrol etme anlamı taşıdığ için daha demokratik bir düzenleme olduğunu söylemek neredeyse imkansızdır (Montin ve diğerleri,1995:75).

1980'lerin sonunda belediyelerde geliştirilmeye çalışılan "sipariş performansı modeli” yeni bir model olarak, politika ve üretim arasındaki ilişkiyi çok tartışılır hale getirmiştir. Bu model belediyelere sipariş komitelerini, kamu hizmeti sunan birimler olarak, oluşturulmasını gerekli k1lıyordu (Montin ve diğerleri,1995:76). Bu model 1991-92 yıllarından itibaren 20 den az belediye tarafından denenmiştir. Fakat bunların çok azı adapte olabilmiştir (Montin ve diğerleri,1995:76) Kimi belediye başkanları bu iki farklı birim üzerine yapılanmanın, yerel politikacılar ve yerel birimler arasına hendek kazdığını iddia etmişlerdir (Larsson ve diğerleri,2008:91).

Belediyelerin firmalaştırılması konusunda 1991 'de yapılan araştırmalar göstermiştir ki, İsveç belediyelerinin neredeyse yarısı bu hedefleri uygulamaya başlamıştır (Montin ve diğerleri,1995:76-77) Ve fakat birkaç tanesi uygulayabilmiştir. Bunun nedeni bu firmalaşma ilkelerinin/kurallarının henüz gelişmemiş olması ve İsveç'in kamusallığın ağır bastığı politik kültürüne doğrudan uymamasıdır. Fakat 2000'li yıllardan itibaren kamusallığın ağır bastığı politik kültür işletme mantığı doğrultusunda esnekleştirilmiştir( Montin ve diğerleri,1995:79).

Bunlara rağmen yeni modelin uygulanmasında kimi konularda başarı sağlanmıştır (Montin ve diğerleri,1995:80-82):

İlk olarak piyasalaşma (kamunun piyasalaşmaya uygun hale getirilmesi), belediyede hizmet sunan birimlerin sözleşmeler için yarışması, böylece hizmet üretiminin daha kaliteli ve verimli olacağı algısının yaygınlaştırılması. İkinci olarak hizmet sunan tarafın bağımsız olabilmesi için üç temel gerekçe açıklanmıştır, etkinlik, etkililik ve verimliliği sağlamak için siparişi alan, talebi belirleyen komite, bu siparişlerin yerine getirilmesi için yerel yönetim içinden veya dışından hizmet sağlayıcı, müşteri ve kullanıcılar arasında gerekli diyalog ve uzlaşmayı kurmaktadır. Yeni kamu işletmeciliği anlayışına bağlı olarak kurulmaya başlanan yeni tür katılımcılık tam da bu noktada devreye girmektedir. Böylece özel sektöre birakılan hizmetler ve müşteri arasında gereksiz hizmet üretimi riski en aza indirilmiş olur. Ayrıca politik kararlar, seçilmiş temsilcilerden oluşan politik birimlerden, sipariş alan ve politik alanın dışında kalan komitelere geçmiş oluyor. Böylece yeni yasada kamu hizmeti, siyasal kontrol süreçlerinden de ayrılmış durumdadır.

\section{SONUÇ}

1930-1970 arasında dünyaya örnek olarak gösterilen İsveç modeli korporatist yap1, 1980'lerden sonra şekil değiştirmeye başlamıştır. Özellikle 1991-94 yılları süresince farklı tür politikalar geliştirilmiştir. Sosyal devlet politikalarının yerine, özelleştirme, şirketleşme ve şirket gibi işleme anlayışının yaygınlaşmış olduğu söylenebilir. Nitekim 1991'de yapılan yeni yerel yönetim yasası önceki başlıklarda ele alındığı şekliyle, yerel yönetimleri, yerel işletme mantığına doğru kaydırmaya başlamıştır. Bu dönemde kamu yönetimi reformlarına yönelik tartışmaları demokrasi ve verimlilik üzerinde yoğunlaştırmıştır. Demokrasiyle ilgili tartışmalar temsili demokrasinin halka uzaklığı, onun yerine katılımcı demokrasi, yerel komitelerin güç, sorumluluk ve yetkilerinin arttırılması üzerine kurgulanırken, komitelerin yerel ihtiyaçlara göre 
ayarlanması ve kamu hizmetlerin özele gördürülmesi ise etkinlik ve verimlilik tartışmaları üzerine kurgulanmıştır. Yerel yönetimler ve özellikle belediyeler için reformların piyasa gibi işleyen yerel yönetimler kısmı önem kazanmış, demokratik tartışmaların önemi azalmıştır.

\section{REFERENCES}

- Anthonsen, M., Lindval, J. (2012) Ulrich Schmidt-Hansen, "Social Democrats, Unions and Corporatism: Denmark and Sweden," SAGE, Party Politics, Vol.17 (1), sf.118-134.

- Bağlija, I. (2008) "Something Old, Something New, Something Borrowed: Political Participation", Jounal of Comparative Politics, Vol.1, No.1, 2008, sf.39-60

- Duros, C., Greasley, S., Richardson, L. (2009) Changing Local Governance, Changing Citizens, Great Britain, UK.

- Elander, I., Montin,S.(1995) "Decentralisation and Control: Central-Local Government Relations in Sweden", Policy and Politics, Vol.18, No.3, sf.167

- Gjelstrup, G., Sorensen, E. (2007) Public Administraration in Transition, DJOF Publishing, Copenhagen.

- Gustafsson, L., Svensson, A. (1999) Public Sector Reform in Sweden, Liber Ekonomi.

- Karlsson, M.(2012) "Participatory Initiatives and Political Representation: The Case of Local Councillors in Sweden", Local Government Studies, Routledge, Vol.38, No.6, sf.795-815.

- Laffin, M. (1986) Professionalism and Policy: The Role of the Professions in the Central-Local Government Relationship, Aldershot: Avebury.

- Larsson, T., Back, H. (2008) Governing and Governance in Sweden, Studentlitteratur.

- Lewin, L. (1994) "The Rise and Decline of Corporatism; Case of Sweden", European Journal of Political Research, Vol.26, sf.59-79

- Montin, S.(2000) The Swedish Model: Many Actors and Few Strong Leaders, in: R.Berg \& N.Rao (Eds), Transforming Local Political Leadership.

- Montin, S., Amna,E.(1999) The Local Government Act and Local Government Reform in Sweden, Bergen: Fagbokforlaget.

- Murphy, K.M. (2009) "A Cultural Geometry: Designing Political Things in Sweden”, American Ethnologist, Vol.40, No.1, sf.118-131.

- Pierre, J., Peters,B.G. (2000) Governace, Politics and the State, Political Analysis, England.

- Premforms, R. (1991) “The Swedish Model and Public Sector Reform", West European Politics, Vol.14, (1), sf. 89-110.

- Rose, L.E., Stahlberg, K. (2005) Nordic Countries: Still The "Promise Land"? in: B.denters \& L.E. Rose (Eds) Comparing Local Governance Trends and Developments, sf. 83-105.

- SALAR, (2006) 11 Thoughts About Citizen Dialogue and Participation in Local Government, Stockholm.

- Strömberg, L., Westerstahl, J. (1984) The New Swedish Communes, A summary of Local Government Researcg, Stockholm:Liber.

- Swedish Local Government Act, Stockholm, 1992:110 (kanun numaras1) 
- Tullock, G. (1965) The Politics of Bureauracy, Public Affairs Press, Washington.

- Wise, C.R. (1998) "Public Service Configurations and Public Organizations: Public Organizations Design in the Post-Privatization Era", Public Administration Review, March/April. 